\title{
Humans, Elephants, Diamonds and Gold: Patterns of Intentional Design in Girolamo Cardano's Natural Philosophy
}

Guido Giglioni

\section{Summary}

Distancing himself from both Aristotelian and Epicurean models of natural change, and resisting delusions of anthropocentric grandeur, Cardano advanced a theory of teleology centred on the notion of non-human selfhood. In keeping with Plato, he argued that nature was ruled by the mind, meaning by "mind" a universal paragon of intelligibility instantiated through patterns of purposive action ("noetic" teleology). This allowed Cardano to defend a theory of natural finalism in which life was regarded as a primordial attribute of being, already in evidence in the most elementary forms of nature, whose main categories were ability to feign, self-interest, self-preservation and indefinite persistence.

Keywords: teleology, nature, self-preservation, mind, life, deception

\section{Introduction}

In De subtilitate (published originally in Nuremberg in 1550), the renowned physician, mathematician and natural philosopher Girolamo Cardano (1501-1576) provides an intriguing account of the creation, full of Platonic resonances. Plato's Timaeus is clearly the main source, but there are also distinctive echoes from Giovanni Pico della Mirandola's Oratio de dignitate hominis (1486). The creator, described by Cardano as the Platonic demiurge, "endowed everything with a soul, and with the best soul he could, by creating living, sentient and even thinking beings":

Guido Giglioni, The Warburg Institute, University of London, School of Advanced Study, Woburn Square, London WC1H 0AB (UK), guido.giglioni@sas.ac.uk 
In doing so, he gifted man with every prerogative. Within the series of living beings and following a certain order, he moved from the most imperfect to the most perfect, according to what could be provided by each particular kind of matter. The beginning was represented by mineral substances, as if they were aborted births, and then metals, plants, sponges, urchins, shellfish, worms, ants, gnats, fish, birds, hares, dogs, elephants and apes. Last to be created was man. ${ }^{1}$

The fact that the human being was the last to be created means for Cardano that his species recapitulates the whole process of creation: "Therefore man, in order to attain all the benefits, was born at the end, after the elements had been broken down, for first plants feed on the elements, animals on plants and man on animals (ex ultimo refractis elementis genitus est; nam primo elementis vescuntur plantae, plantis animalia, animalibus homo)." ${ }^{2}$ Is this a way for Cardano to advocate a form of anthropocentrism? As an epitome of created life, the human being reflects the whole universe, but this does not necessarily mean that the universe is teleologically subservient to human beings. Temporal consummation does not guarantee any right to ontological primacy.

In discussing the question of natural finalism, Cardano does certainly recognize the special place that belongs to man as a creature endowed with consciousness and will. However, the human mind remains for him only a part, important as it may be, of the universal order of things. Nature understood as an active power, actively engaged in shaping and perfecting substances according to criteria of harmony and purposefulness, is a defining feature of Cardano's cosmos. In that cosmos, order reigns over all aspects of reality, and for this reason nature betrays the existence of productive intelligence of a superior kind. Orderly and purposive patterns can be spotted everywhere in the created world, from human beings to metals, as can be seen in another quirky passage from De subtilitate:

It seems to me that nature has fashioned (finxisse) four things with the utmost care. The first of these is the human being, because of a certain divinity in him, not to mention all the other qualities of his. I put the elephant in second place, because of its longevity and docility, with a skin that is as thick as the human one is soft. Then, among the gems, I put the diamond, because of its splendour, hardness and the fact that is not damaged by fire. I leave the fourth place to gold, because it is of the most rarefied and pure substance, it is not affected by rust, does not yield to water, fire or time, and it is as heavy as the diamond is light. ${ }^{3}$

Humans, elephants, diamonds and gold: according to Cardano, they are the best illustration of the fictive and teleological power of nature. The choice

1 Cardano 1663, III, 550a. On Cardano's views on animals, see Giglioni 2002. On the influences that Plato's Timaeus exercised on Renaissance authors, especially through the mediation of Marsilio Ficino, see Allen 2003.

2 Cardano 1663, III, 550b. The representation of the great chain of being in terms of food chain is already in Aristotle. See Politics, I, 8, 1256b.

3 Cardano 1663, III, 561b. 
may appear bizarre to us, but the characteristics through which the four categories stand out from the rest of the natural beings do testify to nature's ability to contrive purposive entities: an almost divine adaptability to reality in the case of human beings; longevity in elephants; resistance to external agents in diamonds; and, finally, durability in gold. ${ }^{4}$ No doubt, one might object that self-preservation and finalism can have an acceptable meaning only when they refer to living organisms (and therefore humans and elephants may have some right to be in the list, but certainly not gold and diamonds). However, for Cardano as for other Renaissance philosophers and physicians, all natural beings are alive and participate to a certain extent in the goal-oriented behaviour of the universe. The question then becomes: How aware are natural beings of their teleological performances? Aristotle, the author of one of the most successful models of philosophical teleology in the Western world, came up with the very original thesis that natural finalism is in fact unintentional. While humans and elephants are capable of a richly structured sentient life, it is very unlikely that gold and diamonds have propensities, and it is even less probable that they have a perception of these propensities. For this reason, Aristotle distinguished very clearly nature from sentience, and considered all natural tendencies (especially the ones affecting the material elements) incapable of perception and selfperception. ${ }^{5}$

As we will see in the course of this article, Cardano did not follow Aristotle's elegant solution ("restrained teleology", as it has been recently described $)^{6}$ and preferred instead to adhere to the Platonic view according to which souls are able to organize natural beings in the best way compatible with all the limitations coming from matter. The original aspect in Cardano's solution, however, lies in the emphasis with which he denied that, in a universe pervaded by the light of the intellect, the human soul may still retain a special prerogative. Therefore, while acknowledging the factitiously and fictitiously purposive nature of human beings (man, as we will see, is for Cardano an animal that is artificiosum as well as fallax), Cardano turns out to be a scathing critic of anthropocentric finalism, with a zest that in many

4 Cardano's championing of elephants as patterns of wisdom and longevity (and therefore purpose and soul) also recurs in De arcanis aeternitatis. See Cardano 1663, X, 5b: "est anima in coelo ut anima in elephante, infinita est ergo illa virtus".

5 On Aristotle's teleology, see Bos 2003; Sedley 1991; Sedley 2010; Gotthelf 2012, esp. 33-44; Reeve 2012,1-24. Like Cardano, Francis Bacon would consider longevity and durability as distinctive marks of life. See the fable of Deucalion and Pyrrha in De sapientia veterum, where lapides terrae symbolize the principia magis communia of "mother" earth (Bacon 1857-1874, VI, 661).

6 Sedley 2010, 6 . 
ways anticipates the attacks that Bacon and Spinoza would level at final causality during the seventeenth century.

In what follows, I will examine Cardano's views on natural teleology, focusing in particular on the complex relationship between nature and soul. As will become apparent, soul is a crucial notion in the universal arrangement of the cosmos. Two principles, in particular, govern Cardano's treatment of the soul: the vital autonomy of each natural form ("each natural being was created for its own sake") and the existence of an all-comprehensive order ("the general good has to be put before the inconvenience of the few"). ${ }^{7}$ In a universe in which humans, elephants, diamonds and gold are singled out as four successful embodiments of natural finality, and in which the criterion of personal advantage (commodum) sometimes seems to prevail over that of human ratio (a camel has its humps to survive in the desert, not to carry human luggage in a more convenient way), ${ }^{8}$ Cardano's model of "oblique" teleology introduces a strikingly original element in the contemporary debate over the nature of life and its multifarious adaptations.

\section{The principles of Cardano's natural philosophy}

In De subtilitate, Cardano distinguishes three levels of reality: substances, their properties and human representations of reality. This distinction can be rephrased as a difference between things that really are and things that only appear to be real. The contrast between reality and appearance, which is the hallmark of Cardano's philosophy, parallels the one among different degrees of knowledge: while the intellect coincides with reality, the senses - both external and internal, up to the imagination and memory - provide more or less likely images of reality. ${ }^{9} \mathrm{Man}$, as we will see in the course of this article, is for Cardano the animal fallax, the "deceiving" creature that alone - both in the sublunary and supralunary world - is capable of taking advantage of the gap between substantiae and repraesentationes for his own private gain. Inevitably, the contrast between reality and appearance, intellect and imagination presents itself again when we address the question concerning the reality of natural purposiveness. To what extent are the adaptations that we see everywhere in the cosmos real expression of nature's teleological

7 Cardano 1663, III, 549b; 55a.

8 Cardano 1663, III, 524b.

9 Cardano 2004, 54: "Constat ergo subtilitas in tribus, substantiis, accidentibus ac repraesentationibus. Eorum enim quorum est scientia aliqua, quaedam sunt, quaedam autem non, sed solum esse videntur. Quae videntur, alia quidem nobis dormientibus, alia autem vigilantibus. Vigilantibus alia per interiores sensus, alia vero per externos." 
activity? Shouldn't we rather agree with Epicurus and Lucretius, and say that finalism is in fact a projection of our mind, a mind that is always too eager to find traces of harmony and purpose in the surrounding reality? Since different degrees of knowledge seem to be linked to different levels of finalism, how intentional can we consider natural finalism to be? Is nature different from the soul, or can it be reduced to the soul? To answer these and other related questions, we need to examine some of the most general assumptions in Cardano's natural philosophy.

In De Subtilitate Cardano lists five fundamental principles of nature: matter (seu hyle), form, soul (which includes mind), space (locus) and motion. Significantly, nature is not included in this list.

Of these principles, they all are eternal and primary according to the genus, otherwise they could not be principles. Mind, matter and space, however, are eternal in themselves. Form and motion are partly eternal (in the celestial substances), partly mortal (in the substances constituted under the sphere of the moon). The soul, with respect to the part through which it understands, is eternal; the rest is mortal. Mind, space and motion are incorporeal, but the mind is completely separated from the body, whereas motion is not without a body. Soul, matter and form are necessarily with a body. Nevertheless, the soul does not seem to be a part of the body. ${ }^{10}$

This excerpt is a characteristic example of the way in which Cardano usually outlines his philosophical arguments. The principles - matter, form, soul, space and motion - are all eternal, but mind, matter and space are "more" eternal than form and motion (if it is sensible to distinguish among degrees of eternity), depending on whether we are referring to the supralunary or the sublunary world, or whether the soul actualizes a body from without or from within. A soul can be eternal when it is linked to the intellect, perishable when it informs a body. Motion, soul, matter and form are always related to a body. Minds are souls at their highest level, and as such they exist separated from a body. In De arcanis aeternitatis, Cardano distinguishes at least "three orders" within the realm of supralunary incorporeal substances, corresponding to demons, celestial minds and God's mind.$^{11}$ Ontologically speaking, incorporeal substances such as minds are more real than corporeal ones. Within the category of incorporeal substances, some are more independent than others. God, the supreme substance, depends on nothing. ${ }^{12}$

Regardless of the many differences that derive from its involvement with corporeal reality, the soul remains for Cardano of a celestial nature and conveys celestial energy throughout the sublunary world:

10 Cardano 2004, 91-92.

11 Cardano 1663, X, 4a.

12 Cardano 2004, 55: "Quae igitur incorporeae, aliae quidem a nullis pendent, sed aliorum sunt causae, aliae ab aliis. Quae a nullis pendeat una tantum est, Deus optimus atque immensus, cuius fabrica est universum ipsum." 
Since all elements [i.e., water, air and earth] are most cold, necessarily they are stirred and mixed by the further addition of heat, and they generate something according to the nature of heat and matter: first moisture, then mushrooms, various kinds of vegetable, then worms and snakes. There is no doubt, therefore, that the soul has a substantial character, for it consists of a certain celestial heat. ${ }^{13}$

Cardano rejects Aristotle's prime matter as a pointless and too abstract a notion, and among the elements he rules out fire as a proper component of material reality. ${ }^{14}$ The elements which constitute matter are therefore only three - earth, air and water - and they are devoid of any form of innate heat. Heat does not derive from matter,for, as already said, it has a celestial origin. ${ }^{15}$ Together with elemental moisture, celestial heat is the only active quality to be operating in the material world. ${ }^{16}$ Although Cardano mentions four kinds of heat - celestial (coelestis), fiery (igneus), natural (naturalis) and putrid (putridus),$-^{17}$ in fact they are all emanations of celestial heat. ${ }^{18}$ Heat, however, is not independently active in nature, for it is regulated by the soul. ${ }^{19}$ This is particularly evident in the case of human beings. Echoing classic Aristotelian loci, Cardano states that "the sun's heat is the cause of the human being, not by itself, but through the soul". ${ }^{20} \mathrm{By}$ combining Aristotle's notion of non-sentient celestial heat with the Hippocratic view of natural heat as a fully purposive agent, Cardano elaborates his own version of animate heat, which represents the foundation of his physics and cosmology. ${ }^{21}$

Natural heat is either soul or not without soul. All compounded bodies are therefore hot, and every warm body is alive, or it hastens to become alive. Celestial heat never refrains from acting until it has generated something, and what celestial heat generates is generated following its own power and intensity. ${ }^{22}$

Cardano's theory of universal animation rests on the ubiquitous presence of celestial heat. It is through celestial heat that knowledge (from the soul, but, on a higher level than the soul, from the intellect itself) is distributed to the cosmos: "Life is communicated more to some beings, less to others,"

13 Cardano 2004, 188.

14 Cardano 1663, II, 284b: "Aristoteles plus nimio res multiplicavit materiam primam ultra elementa, et inter elementa ignem".

15 Cardano 2004, 126: "Nullus calor nisi a caelo, atque ab anima vel luce [...] Omnis enim calor ab astris est." See Cardano 1663, III, pp. 500b-501a.

16 Cardano 2004, 128; Cardano 1663, II, 285a: "Principia ergo omnium dico in his inferioribus calorem a coelestibus demissum, et humidum quod est in ipsis elementis."

17 Cardano 2004, 180.

18 Cardano 2004, 192: "Ergo quum unus sit calor, plures sunt illius modi tum species."

19 Cardano 1663, II, 287.

20 Cardano 1663, II, 288b. For Aristotle's saying “a man and the sun generate man", see Physics, II, 2, 194b13 and Metaphysics, XII, 5, 1071a11-17. See Balme 1990.

21 See for instance the author of Fleshes, in Hippocrates 1995, 133: "I believe that what we call heat is in fact immortal, that it perceives all things, and see, hears and knows all that is and all that will be."

22 Cardano 2004, 190. 
but all of them participate in life, from the minds to the elements, to which "the power of the soul (vis animae) is communicated through nature". ${ }^{23}$ There are as many degrees of life as kinds of forms. Plants have a twofold level of vitality (duplex vitae genus), human beings a fourfold one (quadruplex), for their being is "extremely composite" (maxime compositus). ${ }^{24}$ Cardano's cosmos may be said to be fully animate because it is pervaded by different emanations of celestial heat, from metals to human beings, culminating with the appearance of self-awareness in nature. Compared to stones and metals, plants are "endowed with life in a more clear way", and there is no doubt that they have a soul. However, "none of them knows itself or know what it does". This is the special attribute of animal sentient life..$^{25}$

There is no doubt that the way in which Cardano rearranges the meanings of vital heat, soul and the body within his definition of life is particularly problematic. There are moments when one cannot help having the impression that the soul coincides in fact with celestial heat. In De subtilitate, the interplay of soul, heat and form in the organization of sublunary bodies seems to point in that direction:

The heat we are speaking about here is not a body, nor some kind of impression; therefore it is neither an accident, nor a body penetrable by a body. However, it is said to be corporeal, because it cannot be without a body. It is therefore clear why at the beginning we established that there are five principles everywhere: matter, form, motion, space and soul. However, the soul is a kind of form, but not the one that is originally united with matter (hyle) ${ }^{26}$

The boundary lines dividing forms from souls are clearly blurred. Even more problematic, though, is the resulting consequence: everything is imbued with celestial heat, therefore it is alive, and it has a soul, and this soul is imperishable. Most of all, forms and soul, are all on an ontological par. This means that, with respect to the universal order of life, they are equally alive (eodem modo): "Every soul is thus perennial in the same way, and not, as Plato says, only that of perfect animals, for it would be as if we were saying that the souls of blind and dumb human beings are different from the ones of perfect human beings." ${ }^{27}$

This specific objection to the Platonic view of the souls as principles of life and knowledge arranged within a system of hierarchical levels is crucial to understand Cardano's own view on finalism. While in the order of life, each degree enjoys its own level of teleological autonomy, in the order of knowl-

23 Cardano 1663, II, 296b.

24 Cardano 1663, II, 288b.

25 Cardano 1663, II, 287b. On Cardano's cosmological views, see Ingegno 1980; Maclean 1984; Siraisi 1997; Grafton 1999; Maclean 2008.

26 Cardano 2004, 191.

27 Cardano 2004, 191. 
edge - better, of that particular kind of self-knowledge that constitutes the nucleus of selfhood -, the teleological ordering of nature is based on the awareness of the purpose. In this sense, as I am going to argue in the rest of this article, nature heavily depends on the power of the soul.

\section{Teleology}

Because of the strong emphasis placed on selfhood as the defining trait of the mind, Cardano may be said to advocate a form of latent anthropocentrism. He adds, however, a particular twist to the traditional argument according to which human beings occupy a special place within the plan of creation. Although natural and anatomical observations seem to confirm the view that "man is an animal", nevertheless, human beings can be considered to be animals as much as animals can be said to be plants. Cardano has no qualm about stating that, because of their mind, humans transcend the level of mere animality. In his opinion, a true ontological gap divides the sensitive from the intellective soul. ${ }^{28}$ In De subtilitate, he clarifies this point and identifies four reasons why humans are on a different par with animals. Echoes from Pico's Oratio on human dignity can again be heard in his argument, but, when men are compared with both earthly and celestial animals, Cardano identifies the distinctive feature of human reason in its ability to deceive rather than its ontological incompleteness (the opus indiscretae imaginis, to use Pico's words). ${ }^{29}$

Man was created for four reasons. The first is so that he could know divine things; the second, in order that, as an intermediate substance, he might connect mortal with divine things; the third, to rule over mortal things [...] The fourth reason is that, being a better craftsman, through the very act of thinking (ipsa cogitatione) he could execute everything that could be contrived (excogitari) through the mind, so that he could be a deceitful animal (animal fallax). For non-human animals (belluae) would not be capable of deceiving because of their lack of reason (stultitia), the celestial minds (superi), because of their probity [...] Therefore, through the exercise of his intellect, man makes himself similar to divine substances, whereas he becomes like non-human animals when he turns to wickedness (pravitas). There are thus three kinds of human beings: the divine one, which does not deceive and is not deceived; the human one, which deceives and is not deceived; and the animal one (belluinum), which does

28 Cardano 1663, III, 550b: "Haec fidem facere videntur, quod homo sit animal, hucusque etiam sic esse creditum est. Sed homo non plus est animal quam animal planta. Si enim animal quamvis nutriatur et vivat, plantae nomen meretur, nec omnino planta est, quia animam qua sentit habet praeter plantam; homo cum praeter animal mentem habeat, desinit esse animal; nam alterum genus animae est quod sentit ac intelligit, ut testatur Aristoteles." See Cardano 1663, III, 584b: "Omnibus vero hominibus mens est, nullum animal mentem habet." On Cardano's notion of mens, see Giglioni 2007.

29 Pico 2004, 104. 
not deceive and is deceived. The kind which deceives and is deceived, which alone occupies the greatest part of the genus "human being", is not a simple modality, but results from the combination of the genera "animal" and "human". ${ }^{30}$

Cardano connects the purposive behaviour that is common among human beings to their tendency to manipulate means in order to achieve a particular end. He examines the different degrees of knowledge in nature from the point of view of one's ability to act deceitfully and, within this scheme humanity is characterized by the tendency to deceive without being deceived. Cardano associates the possibility of deception in nature with a surplus of imagination and ingenuity originally granted to human beings, while both earthly and celestial animals are constitutively foreign to the dimension of fiction and fabricated reality (excogitatio, fictio, ingenium). What is more, Cardano is convinced that deception can be seen as a key resource in a natural world in which man was created naked and defenceless. A tendency to self-preservation based on self-awareness and dissimulation is what makes humans different from animals. Cardano considers this characteristic (which at the beginning of this article we call "oblique" teleology) as perilously drifting towards the murky territories of what appears to be real but it is not necessarily so: lies, simulations, errors, contradictions, paradoxes and hypotheses. From this point of view, the human being is a creature in which various strands of teleological behaviour, on both a cosmological and individual level, meet, and often he tweaks means and ends to adapt to specific circumstances:

[Man] was created naked, so that he could be more attractive, of a finer substance and moister. However, since nakedness exposed him to dangers and was less safe, nature armed the human being with defences: skill (ingenium), for the invention of things necessary; language (sermo), for help; and hands, to perfect all the things he had devised through his skill and learnt from other people through language. ${ }^{31}$

30 Cardano 1663, III, 551a. On Cardano's theme of man as the animal fallax and its Erasmian background, see Bietenholz 2009, 151. It is worth pointing out that, according to recent research, human animals share with some non-human animals the dubious honour of being able to deceive other fellow sentient beings. See Carruthers 2011, 254-260; Trivers 2011.

31 Cardano 1663, III, 551b. On the Quintilian locus (Institutio oratoria, I, 1) concerning the link between prudentia, manus and agitatio mentis, see the following passage from Symphorien Champier (1471-1538), a contemporary Galenist with strong Platonic and Hermetic leanings: "Homo non propter manus prudentissimus est, sed quia prudentissimus omnium animalium est, ideo manus obtinet: qui enim prudentissimus est, recte plurimis uti instrumentis potest. Manus autem esse videtur non unum instrumentum, sed multa. Est enim, inquit Aristoteles, instrumentum ante instrumenta. Natura igitur ei qui artes plurimas recipere potest manum addidit, quae ad plura instrumenta utilis est. Quapropter, inquit Lactantius: Hominem, quoniam aeternum animal atque immortale fingebat, non forinsecus ut caetera, sed interius armavit, nec munimentum eius in corpore, sed in animo posuit. Nam, ut Quintilianus scribit, sicut aves ad volatum, equi ad cursum, ad saevitiam ferae gignuntur, sic hominis est propria agitatio mentis atque solertia" (Champier 1532, f. 59v). 
Unlike animals, which are not capable of speaking and have organs that only resemble, but are not hands, human beings can build their own world through the use of their rational capacities, from cloths and houses to the most sophisticated institutions and political organizations. As we have just seen, this ability to re-create the world of nature is heightened by the human skill to create alternative worlds through deception. And there is no doubt that language can be used as the most powerful instrument in this artificial recreation of nature. While animals are parts of a larger teleological plan affecting every aspect of the creation (universal animation), human beings create their own cultural teleologies which culminate in elaborate systems of religious beliefs, with their laws and rites. ${ }^{32}$ We might say that, in Cardano's eyes, human industriousness, when compared to nature, often manifests aspects of purposive behaviour that have gone rogue. ${ }^{33}$

Here it is worth pointing out that in Cardano's philosophy a radical chasm divides natural wisdom from human wisdom. While nature is characterized as wholesome and unaware of any dissociation between perception and reality, mankind, precisely because it is dissociated from both itself and reality, is given to cunning, design - often ill-contrived design - and manipulation. Given these premises, the view that nature has been created by God to serve the needs of human beings appears to Cardano as yet another mystification elaborated by human wisdom. Accordingly, he has no time for philosophers who indulge in anthropocentric fantasies and, in this case, his rejection of harmoniously anthropocentric views of nature is unambiguously clear.

Cardano explores the limits of anthropocentrism in Chapter 11 of $D e$ subtilitate, devoted to "the necessity and form of the human being". In his opinion, the questions to be addressed when dealing with the place of mankind in nature are: "why the whole universe was created"; "whether everything was made for the sake of human beings" and "whether the human being is an animal". Cardano begins his discussion by tackling this last point, with the related corollary about "whether animals and plants have been created for their own sake, or for the sake of man, and, if they are for the sake of man, which order is to be followed: for instance, whether grass is for the benefit of hares, hares for the benefit of foxes, and foxes for the benefit of man". To be sure, as Cardano acknowledges, "one could hardly find a more elegant and difficult question than this". He approaches the discussion about

32 Cardano 1663, III, 551b-553b.

33 Cardano expands on the many aspects of the "oblique" teleology in De sapientia (Cardano 2008). See Giglioni 2006. 
the plausibility of anthropocentrism by quoting Lucretius's famous lines in De rerum natura and referring to the Epicurean solution. ${ }^{34} \mathrm{He}$ acknowledges the strength of the atomistic position whereby nature seems to be a remorselessly creative power (so much so that even monsters are perfectly reasonable occurrences in nature); ultimately, though, he is not convinced by the thesis that nature's creative energy lacks any purpose.

Not a little advantage derives from this opinion of Epicurus, for he is able to explain the cause of monstrous forms: nature is always in the process of testing new animal species, and since these cannot survive, they are viewed as monsters. Epicurus, however, is wrong on two counts. First, he cannot explain why other animal forms that managed to survive could have been created, such as wolves with horns and dogs with pointed claws. Second - and this is an abominable opinion - he thinks that nature created everything at random (quia naturam [pro nephas] vult casu omnia condidisse). ${ }^{35}$

Cardano argues that, as far as the origin of natural forms is concerned, the most plausible hypotheses are fundamentally two: either natural species are limited in number and, however much they may have been variously affected by astral influences, their forms were established from the very beginning of the creation, or species are variable and they change according to environmental conditions. ${ }^{36}$ Of the two positions, Cardano seems to prefer the second one. In both cases, though, he rejects any form of narrow anthropocentrism. In doing so, he embraces an important aspect of the Epicurean and Lucretian thought, i.e., the rejection of the idea that the order of the universe should be based on hierarchical divisions:

As God created man so that he could aptly use everything to his advantage, man appears to have been created so that everything seems to have been made for his own sake. But this is not the case. Each natural being was created for its own sake, nor was the quail made for the falcon any more than animals were made for man. Natural beings that were born in a lower condition seem to have been created for beings that are in a better condition - but this is a wrong assumption. ${ }^{37}$

Cardano sees the notorious example of the fly as particularly to the point: "You may wonder what the use of the fly is, to mention one of the most worth-

34 Cardano 1663, III, 549a. See Lucretius, De rerum natura, V, 837-839; 857-861; 870-871; 874-875: "Multaque cum tellus portenta creare I conata est mira facie membrisque coorta, I androgynem inter utrasque [...] Nam quaecunque vides vesci vitalibus auris, $\mid$ aut dolus aut virtus aut denique mobilitas est, I ex ineunte aevo genus id tutata reservans, I multaque sunt nobis ex utilitate sua I quae commendata manent, tutelae tradita nostrae [...] At quis nil horum tribuit natura, nec ipsa I sponte sua possent ut vivere nec dare nobis, I haec ipsa iacebant [...] indupedita suis fatalibus omnia vinclis I donec ad interitum genus id natura redegit" (Cardano adds "haec ipsa iacebant", which is not in Lucretius' original).

35 Cardano 1663, III, 549a.

36 Cardano 1663, III, 549ab: "Ergo duorum alterum necessarium mihi videtur, vel quod formae viventium numero quorundam et viribus siderum constituantur, vel quod perpetuo varientur temporum successu. Indicio est diversitas illorum in regionibus aliis atque aliis, ut supra demonstratum est, necnon in temporibus."

37 Cardano 1663, III, 549b. 
less and insolent among the animals." His answer shows how the fly contributes to both "the life of its species" and "the beauty of the world":

Flies have been created for their own sake, and not in order to be inimical to man, nor are all flies inimical to men: some remain always in the woods; there are regions where there is no fly, like Lapland, and few flies can be found even in the Western Indies. The fact is that the general good has to be put before the inconvenience of the few. In each single being, divine wisdom made the best of what could be contrived from matter. Sure, many hares are unhappy, but not all of them; some have never seen a man or a dog, nor have been exposed to any form of chasing. ${ }^{38}$

One would think that, when Cardano is criticizing contemporary views of anthropocentric hubris, he is most of all referring to revivals of Hermetic and Platonic philosophy or humanistic praises of the central place held by man in the universe. Surprisingly, as is often the case with Cardano, Aristotelian metaphysics is the main target of his critique. In De arcanis aeternitatis, a work that in all likelihood Cardano began to write at the end of the 1530s, he rejects what he sees as a distinctively Aristotelian strand of anthropocentrism, based on the primacy of the intellectus. ${ }^{39}$ Averroes, quite unexpectedly, is portrayed as the main assertor of this anthropocentric teleology:

\begin{abstract}
In keeping with Aristotle, Averroes burst into these words: If there were no human intellect, all these celestial minds would have no purpose. What an absurd and vainglorious sentence, unworthy of a philosopher! For, if he means that these minds have no purpose because the order of the universe will be violated, and divine wisdom would be defective and imperfect, this sentence is most true. However, it misses the point, for, if the genera of beetles or mice were missing too, the duty of divine wisdom would not be perfect. This, and only this, belongs to God: that everything be done in the best way and nothing be deficient. And if this is understood of human beings as a result of a special reason, it is as if someone were saying that the sky has no purpose if there were no hornets or, lower than them, gnats. The reason behind such a great temerity is ambition. But I, who acknowledge the insignificance of our condition and our ignorance, am not falling into these mistakes. ${ }^{40}$
\end{abstract}

The way Cardano presents Averroes' position is indeed quite odd. If anything, the Averroistic interpretation of Aristotle was being criticized at the time for offering a view of the intellect in which a thoroughly impersonal power was deemed to rule over the cogitative functions of individual human beings. In this sense, Aristotelian-Averroist naturalism advocated a model of cosmological teleology in which no human ends were involved. ${ }^{41}$ Perhaps Cardano is here referring to the elusive and yet crucial role that the human faculty of representation (imagination) plays in Averroes' philosophy in securing a possible connection between human reason and the active intel-

38 Cardano 1663, III, 550a.

39 Maclean 2004, 69.

40 Cardano 1663, X, 3b.

41 Giglioni 2013, 16-21. 
lect, and through this, a connection with the celestial intelligences of the supralunary world. ${ }^{42}$

To be sure, both Aristotle and Averroes would have found many aspects of Cardano's position quite congenial. Because he shuns from the reckless claim that humans enjoy a privileged status in nature, Cardano rules out the possibility that lower living forms had been created "for man's or other animal's advantage". ${ }^{43}$ For instance, as already hinted, to those philosophers and natural historians who claim that "the camel seems to have been created for the sake of human beings, and not for its own sake", he retorts that the function of animal's humps is not that of carrying burdens, but of acting as a supply of food and fluids meant to be used by the animal for its own survival in arid places. The bodily parts of the camel have that particular conformation not because they have to meet human wishes, but for its own wellbeing. ${ }^{44}$ This point becomes even more evident when Cardano addresses the question of the origin and essence of monsters in the natural world. Far from casting doubts upon the reality of design and purpose in nature, aberrations and anomalies demonstrate the more comprehensive character of natural order. Reality swarms with living forms, but many of them do not last as long as elephants and diamonds do. While providing incontrovertible evidence that nature is endowed with inexhaustible creativity (facilitas generationis), monsters remain of a limited lifespan because they deviate from the regular patterns and do not fit the conditions of the environment. In this sense, they are aborted attempts within nature's unremitting teleological activity. As for the few specimens that survive, "the more adapted (commodior) their form is, the longer they live". But it is precisely the appearance of monsters that call into question the foundations of natural finalism. We need to establish, Cardano insists, whether a monster is a "simple mistake of nature" "as when a ram is generated by a human being"), or whether in fact nature "intends to fulfil some ends" through it. ${ }^{45}$ The criterion of advantage and profit (commodum) seems to be a key factor in Cardano's explanation of natural adaptations: "In the chief representative (coryphaeus) of each genus, nature has

42 I have not been able to trace the possible locus in Averroes' works to which Cardano is referring. On Averroes' notion of material intellect and its relationship with the imaginative faculty, see Davidson 1992, 290. On Cardano's relationship with Averroistic Aristotelianism, see Giglioni 2009; García Valverde 2013. On the notion of finis in an Aristotelian-Averroistic meaning, see Zimara 1562-1574, XII, f. 138 ${ }^{\mathrm{r}}$. On the idea of Aristotelian teleology as anthropocentric, David Sedley seems to share Cardano's view. See Sedley 1991, and more recently Sedley 2007, 167-204; Sedley 2010.

43 Cardano 1663, III, 549b.

44 Cardano 1663, III, 524b: "Non igitur hominis gratia haec facta sunt, sed cameli [...] Formae igitur animalibus propriae, proprij etiam commodi causa sunt."

45 Cardano 1663, III, 568b; 569a. 
made a trial (conatus). A crocodile is born from an egg not because it is of a lower condition, like caterpillars, spiders and lizards, but because, as in the case of birds, this reproductive kind is advantageous (ob commodum)." ${ }^{46}$

This means that, within the animal kingdom (and more generally within nature as a whole), the transition from one level of organization to the next is never smooth. All processes of generation follow a number of different strategies and paths that depend on the dispositions and potentialities encompassed by a particular species, the environmental situation at the time and the advantages that the organism can obtain from behaving in a particular way in particular circumstances. The order of nature is vaster and more comprehensive than any scenario deemed to be centred on human ends. Inevitably, these ends are narrow and reductive, whereas natural things refer to a broader system of purposes. For this reason, Cardano does not hesitate to challenge the very notion of end every time this is not related to the "order of the universe". In a grammatically convoluted - but philosophically pointed - passage from his unfinished tract De natura, he brings to the fore the main lines of argument that result from assuming the existence of an infinite number of things in nature, the obvious presence of fortuitous events and the arbitrary tendency among human beings to project moral concerns onto the activity of nature, which, more often than not, is determined in a necessary way, with no purpose in view:

First, since things are infinite, they cannot be reduced to one end. And since it has been acknowledged that a great number of these things happen by chance, they do not happen because of an end and there will be no end in view; we know this by experience. For instance: vapours drawn by the sun's heat, when they all gather into one mass and the rain is thus collected, the rain falls not for sake of wheat, nor is it Jupiter who sent it. And even if he were the one who sent it, he did not this to benefit one thing to the detriment of another. No thunderbolts, poisons or flies are directed to a traveller. Otherwise we would be forced to say: "Where does evil come from?" 47

The conclusion that Cardano draws from these considerations is significant: when we look at purposive processes in animate beings and actions ruled by human will, often they do not necessarily occur for the sake of an end, or, when they do, they happen for a purpose that "can be reduced to the end of the universe". ${ }^{48}$ The truth of the matter is that Cardano has an exceedingly complex view of what one should understand by natural order. Seen as an

46 Cardano 1663, III, 520b.

47 Cardano 1663, II, 292b. The example of the rain is Aristotelian (Physics, II, 8, 198b). See Sedley's fine analysis of the question addressed in that place by Aristotle (Sedley 1991, 181-187). In this case, Cardano diverges quite significantly from Aristotle. "Unde mala" is a possible reference to Boethius, Consolation of Philosophy, I, 4, 105: “'Si quidem deus', inquit, 'est, unde mala?'”. On Cardano's De natura, see Maclean 2004, 108; Maclean 2006.

48 Cardano 1663, II, 292a. 
inextricable tangle of countless interrelated ends, many of which are in conflict with one other, Cardano's order of nature seems to have a number of characteristics in common with Empedocles' and Epicurus' conception of nature as a blind power, acting randomly (natura tanquam caeca et velut ignis agens), in which all creatures struggle for surviving and go to great lengths to adjust to external conditions that are in a state of constant change:

The fact that horses can be tamed serves human beings; swift feet help the hare; strength and inaccessible woods surrounded by water protect the elephant; the sea benefits fish; poison and desert suit snakes, and wings birds. By contrast, all the creatures that lacked some specific characteristic were not able to preserve themselves and died. And not only did the animals that are still being born today exist once; many more of them were alive in the past. Evidence of this are the accounts about centaurs, satyrs, fauns, sphinxes and phoenixes, of which none survives, while there are many birds and animals in our age that were unknown to the ancients. The same is true of plants, among which the balsam-tree has long stopped being most generous. Every single day new creatures are born, which we call monsters, because they cannot perpetuate their kin due to their deficient nature. And if things were ordered according to some end, everything would be everywhere (ubique omnia essent). But this is not the case. Indeed, plants and animals vary according to the nature of their environments (loci).$^{49}$

Unlimited vital creativity, cases of extinction and involution, the reality of teratological productions and environmental constraints: these are all factors that for Cardano should curb our excessive faith in teleological optimism. And yet, for all his leanings towards Empedoclean and Epicurean notions of variability and changeability, Cardano never fully embraces the arguments in favour of random mutability, nor does he deny the reality of finalism. He thinks that, like the Platonic demiurge, God created the world following timeless norms of goodness and beauty, to be adjusted to material reality in the best possible way. To be sure, he wonders whether it is legitimate to compare the work of any craftsman (quivis artifex) with that of the Creator (primus opifex). However, if artefacts (artificiosa) presuppose in the artificer some knowledge of the ends to be achieved and the skill to attain it, this appears to be even more the case with natural beings created by God. ${ }^{50}$ The process of generation is the clearest evidence that life is not just a series of random occurrences: "If no house was ever made out of stones accidentally thrown here and there, even less this may happen with a little worm, for there is much more evidence of skill (plus longe artificij) in this worm than in the grandest mansion." On this particular point, Cardano is in line with Aristotle's principles of natural activity and maintains that the major difference between artificial and natural productions lies in the way the "species", i.e., the essence of the thing to be produced, is ontologically related to the productive agent: "In craftsmen (artifices) the whole species is placed outside

49 Cardano 1663, II, 293a.

50 Cardano 1663, II, 293a. 
them, in natural agents (naturalia) only a minimum is outside, but the greatest part - indeed, almost the whole species - is inside." ${ }^{51}$ That minimum of external conditioning in natural productions is represented by the influence of material limitations, for there may be situations in which the original plan of the creation is impaired and maimed by the opposition of recalcitrant matter: "We should not be surprised if even the most skilful craftsman does not make a stool in the proper manner, because a knot in the wood puts up resistance, and splinters have chipped off and marred his work." The same occurs in nature, where monsters emerge as a result of matter's refractoriness (ex impedimento materiae). It is not simply a question of limitations and mistakes. "In different regions some human beings are black, some are small, some others have a tail. None of these differences depends on the soul, which on all occasions acts unflinchingly in the right way (semper recte agit), but on the quality of the air", which may affect the organs of reproduction in various ways. ${ }^{52}$

The soul is always the same and acts always in the same way; waters, airs and places, by contrast, are constantly changing. In the final analysis, the contrast between final causality and the necessity of matter originates from a deeper tension that differentiates the soul from nature. Cardano argues that Aristotle was not able to defend his position about natural teleology because he incurred in a fundamental inconsistency when defining the spheres of competence pertaining to animal and natural actions. Aristotle, he explains, "because of an ill-posed premise, struggles with vindicating the definition of the end (finis constitutio)". And the principal reason is that "the end presupposes knowledge (finis cognitionem praesupponit)", while nature (in Aristotle's opinion) is "an agent that lacks knowledge (agens quod cognitione caret)". By contrast, Cardano sees his own view of natural finalism as fully compatible with the notion of the soul as a true active principle in nature: "By saying that the soul does this by itself or through the heat or something similar to the heat - for there is no doubt that the soul understands (intelligere) -, I do not incur in any ambiguity concerning the end itself." ${ }^{.53}$

Indeed, Cardano's understanding of the soul as an intellective principle that pervades every aspect of nature allows him to defend a radical form of teleology. The material disposition depends on the purposive organization, not the other way around, because purposive knowledge is the true essence of nature. ${ }^{54}$

51 Cardano 1663, II, 293b. On the same discussion in Aristotle, see Sedley 2010,14-17.

52 Cardano 1663, II, 293ab.

53 Cardano 1663, II, 293b.

54 Cardano 1663, II, 293b. "Materia ergo propter finem est, finis autem non propter materiam.” 
It is not that, because there is a bone, therefore we have an organ of support, but because support is needed, therefore a bone is made. Likewise: in order for a chest to be made, wood is needed, but it is not because of wood that a chest is made. And so on. The end is therefore the cause of the necessity (finis ergo est causa necessitatis) of the things which are according to an end, as the ship is for the end of navigation, and wood is for the ship. ${ }^{55}$

Both Aristotle and Galen would have agreed with Cardano on this point. It is rather with respect to the question concerning "whose benefit" and the kind of knowledge involved in natural purposes that the most significant differences among them emerge. As we have seen, to assume that the human soul is at the centre of the universe is for Cardano the wrong answer, for his model of teleology is not predicated on any delusion of anthropocentric grandeur. Natural finalism à l'Aristotle, on the other hand, despite the high level of speculative sophistication and its elegant dismissal of animistic fallacies, fails to account for that particular kind of knowledge that is supposed to be behind goal-oriented natural actions. Natural purposes are all intentional for Cardano, for nature is a direct manifestation of the soul. The only option left to Cardano seems therefore to revisit the Platonic model of "demiurgic" teleology, in which a creative and organizing mind rules over all purposive operations in the universe, at both a supralunary and sublunary level.

\section{Conclusion: "oblique" versus "noetic" teleology}

Cardano's model of finalism rests on the assumption that the intellects governing the universe have arranged the system of natural ends in the best possible way. This means that, in the end, "oblique" human teleology is in turn wisely controlled by a higher level of purposive understanding (we might call this "noetic" teleology), under the supervision of a cohort of celestial intelligences.

In the animal body, the most important organ is the heart. Cardano defines its motion as "natural", for, "if it does not obey the will, it is involuntary; if the principle of function does not get tired, it is not violent" (in the genuinely Aristotelian sense of "violent", as an action that is caused by the intervention of a force, capable of restarting a process that had come to an end). As a form of natural motion, though, it is a complex one, resulting as it does from an alternated succession of contractions and dilations. Can this alternation of motions be simply attributed to the natural power of heat (calor)? Cardano clarifies this crucial point by introducing a distinction: heat works as an "in-

55 Cardano 1663, II, $293 \mathrm{~b}$.

Gesnerus 71 (2014) 
strument", but the soul is the actual mover (primum movens) behind the heartbeat, and the reason is that, in an Aristotelian sense, "heat cannot draw something to contrary directions, whereas the soul can do it":

[The motion of the heart] is therefore similar to the motion of the heaven, because it derives from the soul; it periodically returns to the starting point, it never stops and it is uniform. The former, however, is compounded of relaxation and contraction, the latter is simple; the former, while not circular, moves from the centre and to the centre (it is the latter that is circular); the former changes according to the passions, the latter occurs without change; the former happens with the mediation of heat, the latter through the soul itself. ${ }^{56}$

Unsurprisingly, in a discussion concerning the place of finalism in nature, the heart represents a paradigmatic case because its motion seems to be natural (involuntary) and animal (voluntary) at the same time. In fact, Cardano maintains that cardiac contractions are entirely ruled by the soul like the heavenly bodies of the supralunary spheres, with the difference that celestial animals are sheer actuality and passionless life in a cycle of eternal recurrence. In a way, the motion of the heart is a clear instance of noetic teleology, as every other motion in the universe. This means that the intellect, through the soul, is the actual principle of motion, and not nature, as Aristotle thought. ${ }^{57}$ Everything that is created, both below and above the Moon, was made from the very beginning in such a way that it is capable of self-preservation. This ability, as all other natural faculties, depends on the "wisdom of nature" (naturae sapientia). But does this stunningly versatile wisdom belong in fact to nature?

Since each single thing has a nature that produces works of art (opera artificiosa) and it does not make any mistake, such nature can only be directed by some kind of wisdom, which we call the "soul". Therefore, why invent so many entities, when one or more souls are sufficient? And if they are many, since all things end into one, they will follow an order. ${ }^{58}$

That nature is inherently "artful" may sound like a contradiction in terms, but it is in fact evidence of a purposive agency which, for Cardano, is intelligent, intentional and deliberate. If nature constantly engages with artificial productions, there has to be knowledge of aims and norms underlying any form of natural activity: hence Cardano's definition of nature as "the impression that a soul has made upon bodies", a definition which in fact resolves nature into the vital knowledge of the soul. ${ }^{59}$

This conversion of nature into soul is also evident in the way in which Cardano interprets Galen's idea of natural faculty. Cardano thinks that, like Aristotle, Galen had arbitrarily separated the domain of nature from that

56 Cardano 1663, III, p. 569b. On the difference between natural and rational powers, see Aristotle, Metaphysics, IX, 5, 1048a; Nicomachean Ethics, I, 13, 1102a; VI, 1, 1139a; 12, 1144a.

57 Cardano 1663, II, 286a.

58 Cardano 1663, II, 286a.

59 Cardano 1663, II, 286a: "Natura est impressio animae facta in corpora." 
of the soul, by assigning the functions of nutrition and generation to natural faculties. By contrast, Cardano is of the opinion that the soul can account for involuntary and natural functions:

If Galen acknowledges that the animal is moved by the soul, and that the human being thinks by virtue of the soul, and he established a soul for the plants, through which they are able to grow, why then is he afraid to say that the work of generation derives from the soul? Isn't the case that the causes of generation and growth are the same? Indeed, the process of generation is a phenomenon that is more creative (res magis artificiosa) and more extraordinary than growth, and yet, for some reason which I don't understand, Galen attributed growth to the soul and generation to nature. And he was so desperately far from finding a solution to this problem that more often than not he mistook this vital soul for nature. ${ }^{60}$

Cardano draws a far-reaching conclusion from his redefinition of the vital functions of the human body: "As we see that in the human being everything is moved by an incorporeal principle, the same happens in the world:"

Regardless of whether the soul is the same as nature or everything is a work of the soul, nature is either nothing or it comes after the soul and depends on it. Therefore we do not see any works of nature apart from the ones made by the soul. That a stone attracts iron or falls down, the work belongs to the soul, as I said, since it takes place with some knowledge. ${ }^{61}$

The soul is therefore "the principle of all beings", for "one is the soul of all things" (unam esse omnium animam) - elephants, gold and diamonds included. And like Cardano at the end his De natura, it seems therefore appropriate to conclude our discussion with the poet's immortal lines:

Spiritus intus alit totamque infusa per orbem

Mens agitat molem, et magno se corpore miscet. ${ }^{62}$

\section{Bibliography}

Allen, Michael J. B., "The Ficinian Timaeus and Renaissance Science”, in: Gretchen J. Reydams-Schils (ed.), Plato's Timaeus as Cultural Icon (Notre Dame 2003) 238-250

Bacon, Francis, Works, ed. by James Spedding, Robert Leslie Ellis and Douglas Denon Heath, 14 vols. (London 1857-1874; repr. Cambridge 2011)

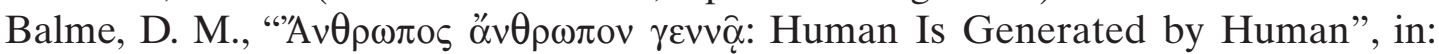
G. R. Dunstan (ed.), The Human Embryo: Aristotle and the Arabic and European Traditions (Exeter 1990) 20-31

Bietenholz, Peter G., Encounters with a Radical Erasmus: Erasmus' Work as a Source of Radical Thought in Early Modern Europe (Toronto/Buffalo/London 2009)

Bos, A. P., The Soul and Its Instrumental Body: A Reinterpretation of Aristotle's Philosophy of Living Nature (Leiden 2003)

60 Cardano 1663, II, 286a.

61 Cardano 1663, II, 286a. See also Cardano 1663, II, 295a: “Quicunque de natura scripserunt animam aut naturae authorem esse dixere, aut ipsam esse naturam."

62 Cardano 1663, II, 296b. Virgil, Aeneid, VI, 726-727. 
Cardano, Girolamo, Opera omnia, ed. Charles Spon, 10 vols (Lyon 1663)

Cardano, Girolamo, De subtilitate (Tomo I, Libri I-VII), ed. by Elio Nenci (Milan 2004)

Cardano, Girolamo, De sapientia libri quinque, ed. by Marco Bracali (Florence 2008)

Carruthers, Peter, The Opacity of Mind: An Integrative Theory of Self-Knowledge (Oxford/New York 2011)

Champier, Symphorien, Claudi Galeni Pergameni campi historiales (Basel 1532)

Davidson, Herbert A., Alfarabi, Avicenna, and Averroes, on Intellect: Their Cosmologies, Theories of the Active Intellect, and Theories of Human Intellect (New York/ Oxford 1992)

García Valverde, José Manuel, "Averroistic Themes in Girolamo Cardano's De Immortalitate Animorum", in Anna Akasoy/Guido Giglioni (eds), Renaissance Averroism and Its Aftermath: Arabic Philosophy in Early Modern Europe (Dordrecht 2013) 145-171

Giglioni, Guido, "Medicina e metafisica della vita animale in Cardano", Bruniana \& Campanelliana 8 (2002) 113-158

Giglioni, Guido, "Girolamo Cardano on the Passions and Their Treatment", Bruniana \& Campanelliana 12 (2006) 25-40

Giglioni, Guido, "Mens in Girolamo Cardano", in: Eugenio Canone (ed.), Per una storia del concetto di mente, 2 vols (Florence 2005-2007), II, 83-122

Giglioni, Guido, "Nature and Demons. Girolamo Cardano Interpreter of Pietro d'Abano", in: Charles Burnett/José Meirinhos/Jacqueline Hamesse (eds), Continuities and Disruptions between the Middle Ages and the Renaissance (LouvainLa Neuve 2009) 89-112

Giglioni, Guido,"Introduction”, in: Anna Akasoy/Guido Giglioni (eds), Renaissance Averroism and Its Aftermath: Arabic Philosophy in Early Modern Europe (Dordrecht 2013) 1-34

Gotthelf,Allan, Teleology, First Principles, and Scientific Method in Aristotle's Biology (Oxford 2012)

Grafton, Anthony, Cardano's Cosmos: The Worlds and Works of a Renaissance Astrologer (Cambridge, MA 1999)

Hippocrates, Fleshes, ed. by Paul Potter (Cambridge, MA 1995)

Ingegno, Alfonso, Saggio sulla filosofia di Cardano (Florence 1980)

Maclean, Ian, “The Interpretation of Natural Signs: Cardano's De Subtilitate Versus Scaliger's Exercitationes", in: Brian Vickers (ed.), Occult and Scientific Mentalities in the Renaissance (Cambridge 1984) 31-52

Maclean, Ian, "A Chronology of the Composition of Cardano's Works", in: Girolamo Cardano, De Libris Propriis: The Editions of 1544, 1550, 1557, 1562 with Supplementary Material, ed. by I. Maclean (Milan 2004) 43-112

Maclean, Ian, "Girolamo Cardano: The Last Years of a Polymath", Renaissance Studies 21 (2006) 587-607

Maclean, Ian, "Cardano's Eclectic Psychology and Its Critique by Julius Caesar Scaliger", Vivarium 46 (2008) 392-417

Pico della Mirandola, Giovanni, De hominis dignitate, ed. by Eugenio Garin (Turin 2004)

Reeve, C. D. C., Action, Contemplation, and Happiness: An Essay on Aristotle (Cambridge, MA 2012) 
Sedley, David, "Is Aristotle's Teleology Anthropocentric?", Phronesis 36 (1991) 179-196

Sedley, David, Creationism and Its Critics in Antiquity (Berkeley/Los Angeles/London 2007)

Sedley, David, "Teleology, Aristotelian and Platonic", in: James G. Lennox/Robert Bolton (eds), Being, Nature, and Life in Aristotle (Cambridge 2010) 5-29

Siraisi, Nancy, The Clock and the Mirror: Girolamo Cardano and Renaissance Medicine (Princeton 1997)

Trivers, Robert, The Folly of Fools: The Logic of Deceit and Self-Deception in Human Life (New York 2011)

Zimara, Marcantonio, "Tabula dilucidationum in dictis Aristotelis et Averrois", in: Aristotelis opera cum Averrois commentariis, 12 vols (Venice 1562; repr. Frankfurt 1962), XII 